$2-3-2020$

\title{
An Exploration of Correctional Counselor Workloads in a Midwestern State
}

Adam K. Matz

University of North Dakota, adam.matz@und.edu

Nathan C. Lowe

How does access to this work benefit you? Let us know!

Follow this and additional works at: https://commons.und.edu/cj-fac

Part of the Criminology and Criminal Justice Commons

\section{Recommended Citation}

Adam K. Matz and Nathan C. Lowe. "An Exploration of Correctional Counselor Workloads in a Midwestern State" (2020). Criminal Justice Faculty Publications. 3.

https://commons.und.edu/cj-fac/3

This Article is brought to you for free and open access by the Department of Criminal Justice at UND Scholarly Commons. It has been accepted for inclusion in Criminal Justice Faculty Publications by an authorized administrator of UND Scholarly Commons. For more information, please contact und.commons@library.und.edu. 


\title{
An Exploration of Correctional Counselor Workloads in a Midwestern State
}

\author{
Adam K. Matz, Ph.D. \\ Assistant Professor \\ Department of Criminal Justice \\ College of Arts \& Sciences \\ University of North Dakota \\ Columbia Hall, Room 1105A \\ 501 N Columbia Rd Stop 8050 \\ Grand Forks, ND 58202 \\ Nathan C. Lowe, Ph.D. \\ Program Director, Grants \& Research \\ American Probation and Parole Association \\ Council of State Governments \\ 1776 Avenue of the States \\ Lexington, KY 40511 \\ 859.244.8057 \\ nlowe@csg.org
}

\section{Declaration of Conflicting Interests}

The author(s) declared no potential conflicts of interest with respect to the research, authorship, and/or publication of this article.

\section{Funding}

The author(s) disclosed receipt of the following financial support for the research, authorship, and/or publication of this article: Data in this article was collected as part of an American Probation and Parole Association project, funded through a subcontract with the Iowa Department of Corrections (IDOC) in response to a competitive solicitation [Project No. RFB0516238102] associated with the Bureau of Justice Assistance (BJA) Statewide Recidivism Reduction (SRR) initiative. 


\begin{abstract}
Time studies have been conducted with a variety of occupations. However, no known research has examined the workload of correctional counselors. The Iowa Department of Corrections, in partnership with the American Probation and Parole Association, performed the first known workload evaluation of this population. Over a hundred correctional counselors participated in a time study informed by a task analysis conducted with a representative advisory committee. The most common activities concerned inmate requests, classification, assessment, release planning, treatment group work, and administrative tasks. Most concerning, respondents indicated anywhere from 20-to-50\% of the activities engaged in were unsatisfactorily completed.
\end{abstract}

\title{
Keywords
}

Correctional counselors, workload, prison, adequacy of time 


\section{Introduction}

The U.S. continues to be the world leader in incarceration (Coyle, Fair, Jacobson, \& Walmsley, 2016; Walmsley, 2018). Despite a slight (1\%) decline from 2016 to 2017, there remains in excess of 1.5 million adults incarcerated in state and federal prisons (Carson, 2018). Notably, the Federal Bureau of Prisons accounts for 37\% of this recent decline. On the other hand, several states including Illinois, Nebraska, Iowa, Delaware, Colorado, and Virginia operate their prisons well beyond capacity. Specific to this research, Iowa operates at $115 \%$ of its capacity. While Iowa’s institutions are designed to hold 7,288 prisoners, as of 2017 it housed 8,378 (Carson, 2018, p. 21). Further compounding this dilemma is the state's persistent recidivism, which has steadily ranged from 30-35\% over the past decade (Iowa Department of Corrections [IDOC], 2016).

In an attempt to improve services and reduce recidivism, the IDOC sought support, funding, and guidance through the Second Chance Act Statewide Recidivism Reduction (SRR) program (Council of State Governments Justice Center, 2018a). SRR is a federal initiative implemented in 2012 by the Bureau of Justice Assistance (BJA). Through this initiative BJA sought to support states in need by implementing evidence-based practices (EBPs) and core correctional practices (CCPs). While numerous states have received an award through this program, Iowa is one of only eight states that received multiple federal grant awards under this initiative (Council of State Governments Justice Center, 2018b). The Iowa SRR initiative, specifically, was initiated in 2015.

While the IDOC conducted an inventory of its programming (Council of State Governments Justice Center, 2018c), it also sought a review of its correctional counselor staffing allocations and workloads. It was reasoned that without adequate staffing and a comprehensive 
understanding of counselor workloads, the implementation of any new strategies would be jeopardized (e.g., see discussion of Florida's early attempt to implement EBPs in Greenwood, 2014). Given the lack of prior research with this population, IDOC subcontracted the American Probation and Parole Association (APPA) based, in part, on the organization's prior workload research experience with community supervision officers (Burrell, 2006; DeMichele, 2008; DeMichele \& Payne, 2018; 2012; 2007; DeMichele, Payne, \& Matz, 2011; Matz, Conley, \& Johanneson, 2018; Payne \& DeMichele, 2011). This research was exploratory in nature, seeking to understand 1) what were the most common tasks performed by correctional counselors, 2) how much time was associated with these tasks, and 3) were there tasks where counselors felt quality was being sacrificed for efficiency?

\section{Literature Review}

\section{Correctional Counseling}

The earliest forms of counseling in correctional institutions were provided by ministers (e.g., Sundt, Dammer, \& Cullen, 2002), probation officers, and parole officers; later supplanted by psychiatrists, psychologists, sociologists, and social workers (Hanser \& Mire, 2011). The concept of correctional counseling became common practice and reached prominence during the rehabilitation era of the 1960s and 1970s. Schrink (1997) defines correctional counseling as;

...an intensive, purposeful, interactive process between a counselor who is professionally prepared to deal with the special problems posed by a correctional environment and a client who has been found guilty of committing a crime or act of delinquency and placed in a correctional institution, facility or agency. The goals of these encounters are to assist the client in better dealing with his or her immediate situation and ultimately to help him or her develop the skills and resources necessary to become a law-abiding citizen. (p. 42) 
Hanser and Mire (2011) similarly describe it as the process by which trained counselors help inmates “....identify and incorporate better behavioral, psychological, and emotional responses to life events that serve to improve their quality of life and reduce or eliminate their involvement in criminal activity” (p. 4) (for more see Gill, 2003; Kelley, 2008; Kennedy, 1984; Kratcoski, 2004; Lehman, Greener, Rowan-Szal, \& Flynn, 2012; Schrink \& Hamm, 1989; Sun, 2008; Van Voorhis \& Salisbury, 2014; Van Wormer, 1999). As Schrink (1997) explains, the only distinction from other forms of counseling is the application to the correctional setting. Unlike counselors outside of institutions, correctional counselors must also look after the custody needs of their clients (Carrola, DeMatthews, Shin, \& Corbin-Burdick, 2016).

In terms of constituting a distinct professional occupation, the term correctional counselor lacks any standardized definition (Hanser \& Mire, 2011; Schrink, 1997). Though not recognized as an explicitly distinct occupation, the Bureau of Labor Statistics does recognize it within the broader category of probation officers and correctional treatment specialists. In some jurisdictions correctional counseling may still be carried out by probation and parole officers (Van Wormer, 1999), or combined with the duties of a correctional officer (Schrink, 1997). Further, the roles and responsibilities of correctional counselors have generally been vague and poorly defined. Schrink (1997) identified seven core duties; 1) maintain caseload files, 2) develop treatment plans, 3) monitor inmate progress, 4) produce agency reports, 5) conduct individual and group counseling, 6) support inmates in correspondences with other staff, and 7) provide treatment and security recommendations for inmates under their purview.

The Iowa Department of Corrections (IDOC), specifically, defines a correctional counselor as the following: 
Provides individual and group guidance and related counseling services to institutionalized residents in a correctional facility in the areas of social, behavioral, educational, vocational and related program planning; participates in the development and implementation of specific plans and goals for rehabilitation and gradual reintegration into the community; performs related work as required.

Given correctional counselors rely greatly on group therapy, limited time is available for one-on-one contact with inmates. As a result, developing close working relationships with treatment staff and custody staff is considered essential (Schrink, 1997). Treatment staff bring a wealth of educational information and insight while the custody staff will often have greater durations of direct sight and contact with inmates, including behavioral observations of interest to the counselor. Indeed, correctional counselors in prisons are primarily concerned with day-today crises and less emphasis may be placed on deeply-rooted behavioral problems. Institutional adjustment, for example, can often be difficult for new inmates requiring an exuberant amount of the counselor's attention. Other documented issues faced by correctional counselors include prison overcrowding, poor institutional support, disproportionate racial and ethnic representation, confidentiality concerns, excessive caseloads, excessive paperwork, coerced counseling (i.e., inmate resistance), role ambiguity, lack of real-world problem-solving application (due to institutional setting), poor rapport building opportunities (a.k.a., therapeutic alliance), overemphasis on failures by administration and the public, stress, and burnout (Carrola, Olivarez, \& Karcher, 2016; Hanser \& Mire, 2011). Yet in addition to their institutional orientation correctional counselors are also expected to be the primary driver of successful prisoner release and community reentry. 


\section{Time Studies}

While numerous time studies and workload evaluations have been conducted in other justice settings (e.g., judges, prosecutors, probation and parole officers) (e.g., American Prosecutors Research Institute \& Bureau of Justice Assistance, 2002; DeMichele et al., 2011; Kleiman, Lee, \& Ostrom, 2013), this is the first known time study specific to correctional counselors. Time studies are not unique to criminal justice (e.g., Alghamdi, 2016; Twigg \& Duffield, 2008) and possess a lengthy history dating back to the 1880s (Miles, 1969).

Times studies have not, however, been the focus of empirical examination in our field with few appearing in scientific journals (DeMichele \& Payne, 2018; DeMichele \& Payne, 2012; DeMichele \& Payne, 2007; Matz et al., 2018). Rather, most have appeared as agency reports which may or may not be made available to the public. Indeed, publication bias is certainly a concern (Cooper, 2010). Nonetheless, some organizations such as the National Center for State Courts (NCSC) have published numerous workload studies from across the country and made their reports readily available (Kleiman, Lee, \& Ostrom, 2013). There are others however, such as studies conducted by Hardyman (2001; 1999) which despite being funded by the National Institute of Corrections (NIC) can prove more difficult to locate and retrieve. According to Wagner and Connell (2004) NIC has reportedly conducted over 80 such evaluations, yet they are not retrievable in any systematic way. The use of ad hoc consultants has likely contributed to a disjointed collection of technical reports scattered across state agencies and research firms (e.g., Sterling Associates, 2002; Washington Department of Corrections, 2005).

A likely reason for the lack of empirical interest is the emphasis on fiscal concerns (Matz et al., 2018). In most cases the aim is to get the state legislature to support the hiring of more positions or, at the very least, protect existing staffing allocations. It is unclear to what extent 
agencies have been successful in procuring further support, though reports have tended to provide favorable recommendations (Bemus, 1990; Tallarico, Douglas, \& Fogg, 2010; Tallarico, Douglas, Kinney, \& Murphy, 2007; Tallarico, Douglas, Tomlinson, \& Hall, 2010; Wagner \& Connell, 2004). Alternatively, some studies may provide general guidance in lieu of explicit enumerations (Griesse, 2008; Hardyman, 2001; Hardyman, 1999; Tallarico, Douglas, Friess, \& Hall, 2009; Sterling Associates, 2002; Washington Department of Corrections, 2005) or expose the need for alterations in current practices (Bercovitz, Bemus, \& Hendricks, 1993; Cuddeback, Gayman, \& Bradley-Engen, 2011).

In terms of methodology, time studies can consist of straight-forward data collection periods, typically four weeks (DeMichele \& Payne, 2018; Matz et al., 2018; Hardyman, 2001; 1999), which involve staff manually tracking their time on a variety of pre-established activities of interest. This may be further supplemented by attitudinal and opinion-based surveys (Tallarico et al., 2010, 2009, 2007). Kleiman and colleagues (2013) note effective workload assessment requires active engagement with practitioners and their involvement throughout the project, usually operationalized through an ad hoc working group or committee. NCSC recommends the use of a pseudo-Delphi approach by placing greater emphasis on the input, feedback, and opinions of practitioners (for more on the Delphi Method see Anderst, Teran, Dowd, Simon, \& Schnitzer, 2015; Edwards, Hughes, \& Lord, 2013; Fletcher \& Marchildon, 2014; Gavrielides, 2008; Green, 2014). Such feedback becomes essential in addressing the need to weigh certain tasks and activities, especially in the event the agency wishes to alter, eliminate, or re-prioritize specific practices (for more on weighting see Chapman, 1972; Kleiman et al., 2013; Orme, 1988). 


\section{Methods}

The current study adapted the time study methodology for use with correctional counselors. With the input of an advisory committee of subject matter experts gathered from correctional facilities across Iowa, a task analysis was conducted resulting in a list of core correctional counselor activities (see also DeMichele \& Payne, 2018; Matz et al., 2018). This list was integrated into a time study form and online application (developed and maintained by IDOC’s IT department) that study participants used to track the time (in minutes) engaged in a given activity over a four-week time period. In addition to tracking the activity type and time (including any travel and wait time), correctional counselors recorded person(s) involved, method of contact, location, related form(s) or assessment(s), adequacy of time, task completion, and noted barriers.

The time study instrument was pretested twice, once in paper form and again as a webbased application, with three correctional counselors. Each counselor was asked to spend a day documenting their activities and then participated in debriefing sessions. These debriefing sessions, as well as consultation with the advisory committee, led to refinements to the instrument including the activity list. All correctional counselors were invited to participate in the study and provided a brief webinar training on how to participate one week prior to the start of the data collection period. To preserve confidentiality, APPA provided unique identification numbers for each participant. Staff associated all the activities they recorded with their ID number and only the principal investigator at APPA had access to the participant key (subsequently destroyed). Interim data checks were conducted each week. At the conclusion of the data collection period, participants were provided one additional week to make final additions and edits to their data. The dataset was then extracted for analysis, supplemented with 
inmate data provided by the IDOC. Note, this project was reviewed and approved by the Iowa Department of Human Rights, Division of Criminal \& Juvenile Justice Planning, Institutional Review Board.

\section{Sample}

Of the 119 individuals employed as correctional counselors at the time 117 participated in the time study (98.3\%). That said, the depth of participation throughout the data collection period varied, with about $44 \%$ documenting what would constitute a complete record based on the total time reported. Table 1 displays demographical information for the study participants. Representation from each facility across the state was confirmed, though nine (7.7\%) chose not to specify the location in which they worked. There were slightly more male $(n=64,54.7 \%)$ correctional counselors than female ( $n=53,45.3 \%)$. Most were white ( $n=89,76.1 \%)$, with one (0.9\%) American Indian or Alaskan Native, seven (6.0\%) African American, while six (5.1\%) marked other and the remaining 14 (12.0\%) chose not to specify their race. In addition, only three (2.6\%) indicated they were Hispanic or Latino. The average age of correctional counselors was 48 with a standard deviation of 10 years, meaning on average a respondent's age varied about 10 years from the mean. Note 11 participants did not provide age information. On average counselors had worked in their current position for 11 years with a standard deviation of eight years, meaning officers generally ranged between three and 20 years in experience. The average was slightly higher for years employed at the IDOC with an average of 15 years and a standard deviation of nine years. Note 11 chose not to respond to years in current position and nine chose not to respondent to years at the IDOC. Nonresponse can be attributed to some participants continued concerns about preserving their confidentiality. 
Insert Table 1

Table 1 also provides demographical information on 4,844 inmates directly associated with the correctional counselors’ activities, excluding inmate group activities. In terms of classification 306 (6.3\%) were maximum, 3,018 (62.3\%) medium, and 1,428 (29.5\%) minimum custody level. There were no classification data for 92 (1.9\%) inmates. The inmate population was predominantly male $(n=4,48192.5 \%)$; white $(n=3,492,72.1 \%)$ or African American $(n=$ 1,237, 25.5\%); English-speaking ( $n=4,283,88.4 \%)$; and in possession of a high school degree $(n=1,418,29.3 \%)$, GED $(n=2,014,41.6 \%)$, or less $(n=1137,23.5 \%)$. Data concerning age for the inmate population has been omitted due to quality concerns (i.e., missing and erroneous entries).

\section{Findings}

One hundred and seventeen correctional counselors reported 31,352 activities, comprising 949,738 minutes (or 15,829 hours), including work associated with 4,844 inmates, over a four-week time period (20 business days). This calculation also includes any miscellaneous wait or travel time. The workload ceiling for this study period was 17,550 hours (assuming a 37.5-hour work week). Though this sample initially shows a 1,721-hour shortfall, recall only $44 \%$ of the sample provided a complete record of their activities. By comparison, the total hours recorded was only $9 \%$ short of the ceiling. In other words, if all officers provided a complete record of their workload it is likely, if not inevitable, that the 17,550-hour ceiling would have been exceeded (indicative of systemic overtime). 
Insert Table 2

As displayed in Table 2, while inmate requests were the most common in terms of frequency at 15.9\% ( $n=4,971)$, administrative work (e.g., time sheet completion, personnel forms, office needs, technical issues, staff meetings) was the most taxing in terms of actual time consumed at 110,474 minutes $(n=4,596)$, followed closely by treatment group work at 103,838 ( $n=1,574)$ minutes and professional development (e.g., continued education, staff training, eLearning) at 103,673 minutes ( $n=849)$. Interestingly, activities that generally do not involve direct interaction with inmates constitute about $28 \%$ of counselors' time. This includes administrative work and professional development, but also coverage work (for other counselors or correctional officers), program sponsorship tasks (e.g., fundraisers, support for public initiatives), quality assurance (e.g., program audits), and court reporting (e.g., progress reports). About 9\% of counselors' time per month is lost to personal leave (i.e., vacation, sick time). As a result, about $60 \%$ of a correctional counselor's time is devoted specifically to inmate-focused work. Such tasks were broken down into 14 categories. Recall these categories are the result of a task analysis completed with an IDOC advisory committee and, in order of greatest frequency, consist of inmate requests, inmate work, classification, assessment, release planning, treatment group work, reception work, Iowa Corrections Offender Network (ICON) entries, institutional case plans, security checks, inmate checks, special lists, sex offender work, and keep separates work. In terms of actual time across counselors treatment group work was the most voluminous, averaging about one hour per session, though it could vary from a half an hour to an hour and a half as evidenced by the standard deviation. Indeed, the core function of correctional counseling 
at IDOC involves scheduled and organized group sessions (note this includes time for preparation, reviewing treatment session notes, and facilitation). Inmate requests (e.g., property issues, phone, visitation), by comparison, are very frequent but less voluminous at 84,525 minutes, with a given interaction or event averaging about 17 minutes. However, it is the most frequent and second-most prevalent of the inmate-focused activities. In other words, correctional counselors spend nearly as much time dealing with miscellaneous inmate needs as they do in providing actual treatment. A great deal of time is also spent on proper assessment and classification at 56,908 and 59,150 minutes, respectively. Case and release planning are also noteworthy demands at 41,244 and 22,991 minutes. The remaining activities largely concern institutional needs around security (e.g., security checks, keep separates), special populations (e.g., sex offenders), and record keeping through ICON.

In addition to tracking the time associated with these activities, correctional counselors were also asked to indicate the extent to which they had adequate time to complete each task, also reported in Table 2. The results are concerning given the lowest proportion of any activity deemed to have inadequate time was about $20 \%$. The most prominent issues of inadequate time were associated with assessment (49.8\%), reception work (46.2\%), and inmate checks (45.3\%). Regardless of the activity, the counselors reported anywhere from 20-50\% were not satisfactorily completed.

Insert Table 3

Table 3 provides additional context to the activities displayed in Table 2 by providing descriptive information concerning the persons involved and the method of contact in which 
activities occurred. Unsurprisingly, a large proportion of correctional counselors' workload involves solitary activities (e.g., paperwork, data entry) or work concerning specific inmates. Note the discrepancy between the time associated with groups of inmates here versus that of treatment group work in Table 2. This is due to the activity encompassing not only the facilitation of group meetings but also the preparation of such meetings (documented as a solitary activity). Certainly correctional counselors interact with a variety of individuals, but the majority of their work consist of inmate interactions or solitary documentation and preparation. In terms of contact methods, a majority of communications, over 70\%, will occur in-person (38.3\%) or through electronic means (34.9\%).

Though not displayed, the office was by far the most predominant place where work was completed. About 78\% $(n=24,506)$ of the activities reported were conducted in the office, constituting 533,208 minutes of correctional counselors' time (56\%). No other location came close (including housing unit, other buildings at the institution, or treatment classrooms).

While obtaining a descriptive profile of correctional counselor workloads and identifying areas of concern were the primary goals of the study, time directly associated with inmates was also explored. Specifically, the relationship between custody level, risk, and known demographic characteristics of the inmate population. This required altering the unit of analysis to that of the inmate (as opposed to Tables 2 and 3 in which the activity served as the unit of observation). When collapsing the data in this manner all time associated with a given inmate was summed, representing any and all activities involving that individual regardless of the counselor that engaged with them or engaged in an activity relevant to them.

First, we examined the extent to which time associated with inmates was statistically significant by risk level, as measured by the Iowa Board of Parole (BOP) risk assessment 
instrument (for more information on this instrument see Davidson, 2012), resulting in classifications of very high $(n=279)$, high $(n=1,067)$, moderate $(n=1,452)$, or low risk $(n=$ 1,177). A Kruskal-Wallis H test, the nonparametric equivalent of ANOVA, was used to statistically test whether there were significant differences in time allocated between risk levels. Unlike ANOVA, the Kruskal-Wallis $\mathrm{H}$ test does not require the data be normally distributed. An examination of histograms makes it clear the data were positively skewed, violating an assumption of ANOVA and necessitating the use of a nonparametric statistic (Fahoome, 2002; Frankfort-Nachmias \& Leon-Guerrero, 2011; Salkind, 2011). Results of the Kruskal-Wallis H test indicated there were no statistically significant differences in the time devoted to inmates by a given risk level, $\chi^{2}(3)=5.604, p=.133(n=3,975)$. Second, these analyses were repeated for each classification level (maximum, medium, and minimum custody) but the results remained the same, the risk level of the inmate was not associated with the amount of time counselors engaged with or performed tasks specific to an inmate. On average counselors spent about one hour (per month) engaged in activities specific to a given inmate, not including involvement in group treatment sessions.

Finally, analyses were conducted to test for possible discrepancies by inmate demographics. The Mann-Whitney U test, another nonparametric statistic, was used in lieu of the independent-samples t-test due to the non-normally distributed data (Frankfort-Nachmias \& Leon-Guerrero, 2011; Salkind, 2011). However, these results were also not statistically significant, indicating the time associated with inmates was not biased by sex $(p=.617)$ or race $(p=.570)$. 


\section{Discussion}

Using the profile of correctional counselor workload provided in this study as a baseline, the IDOC constructed a workload formula that integrated the agency's leadership priorities and goals with the reality of current practices. Specifically, the agency continues to seek a greater institutionalization of evidence-based programming through the SRR initiative, with the intent that such programming will lead to significant reductions in recidivism (for further discussion see Lee, 2017). Implementation of such programming is contingent on the ability of its workforce to implement it with fidelity. Informed by the high percentage of tasks in which counselors indicated there was insufficient time for satisfactory completion, the agency proposed the addition of 32 correctional counselors (for more on how agencies construct workload formulas see Kleiman et al., 2013). Unfortunately, in 2017 the state experienced a budget deficit that adversely impacted the IDOC, resulting in the consolidation and elimination of some smaller facilities and programs (Ringgenberg, 2017). The state's financial climate has since stalled any progress towards improving staffing allocations.

However, IDOC has continued to provide training and support through its federally funded SRR initiative in terms of implementing core correctional practices and improved risk assessment (Dowden \& Andrews, 2004; Haas \& Spence, 2016). Absent an increase in staffing, this research has also encouraged the agency to consider opportunities for reducing inefficiencies. In other words, what can be done to reduce the counselors' administrative burdens, which recall comprised a large proportion, about $12 \%$, of their time. Indeed, more time was recorded for administrative duties than treatment groups or one-on-one interactions with inmates, the most important functions of the occupation. As a result, efforts are also underway to 
streamline and reduce superfluous paperwork. Indeed, investments in training will mean little if correctional counselors lack the time to engage meaningfully with the inmate population.

Though it was not a focus of this research; Carrola and colleagues' (2016) prior work examining burnout among correctional counselors at an unspecified Southwestern location in the US is relevant to a broader consideration of the correctional environment. In their research they found correctional counselors possessed elevated rates of burnout compared to other professionalized counselors (e.g., community counselors, school counselors). This burnout was most notable among those working in maximum custody facilities, likely the most difficult and unruly of inmates. Though it cannot be empirically verified, we suspect such burnout is a reflection, whole or in part, of excessive and unrealistic workload demands. Further research, however, is needed to verify this assertion.

Though an aggregated examination of correctional counselors’ time provides many interesting insights into the occupation, this study made no assumptions about the skill or effectiveness of a given individual or the treatment sessions they facilitated. No attempt was made to validate existing practices or assessments, nor examine the fidelity of newly implemented practices or programs. While the information provided herein may prove informative to other states that employ similar positions, it must also be recognized the data reported may not be generalizable. There is some confusion concerning the exact definition of a correctional counselor, as well as their roles and responsibilities which may vary not only by state but from one jurisdiction to another (Hanser \& Mire, 2011). While conducting the task analysis for this study, the advisory committee often ran into discrepancies concerning practices across different facilities. Some even found they had developed jargon unique to their region that differed significantly from the others. While attempts were made, and a great deal of time and 
effort expended, to reconcile and reduce divergent terminology to ensure applicability to the state more broadly, concerns of content validity are evident and persisted throughout the project

(Carmines \& Zeller, 1979). A clearer framework of what specifically constitutes correctional counseling, and a more definitive recognition of the occupation, is needed. Indeed, the paucity of research specific to correctional counselors in general is problematic. 


\section{References}

Alghamdi, M. G. (2016). Nursing workload: A concept analysis. Journal of Nursing Management, 24(4), 449-457.

American Prosecutors Research Institute \& Bureau of Justice Assistance. (2002). How many cases should a prosecutor handle? Results of a national workload asssessment project. Alexandria, VA.

Anderst, J., Teran, P., Dowd, M. D., Simon, S., \& Schnitzer, P. (2015). The association of the Rapid Assessment of Supervision Scale score and unintentional childhood injury. Child Maltreatment, 20(2), 141-145.

Bemus, B. (1990). Colorado Judicial Department probation officer workload study. Denver, CO: Office of the State Court Administrator.

Bercovitz, J., Bemus, B., \& Hendricks, W. S. (1993). Probation case classification \& workload measures system for Indiana. Indianapolis, IN: Indiana Judicial Center.

Burrell, W. D. (2006). Caseload standards for probation and parole. Lexington, KY: Council of State Governments, American Probation and Parole Association.

Carmines, E. G., \& Zeller, R. A. (1979). Reliability and validity assessment. Thousand Oaks, CA: Sage.

Carrola, P. A., DeMatthews, D. E., Shin, S. M., \& Corbin-Burdick, M. F. (2016). Correctional counseling supervision: How supervisors manage the duality of security and mental health needs. The Clinical Supervisor, 35(2), 249-267.

Carrola, P. A., Olivarez, A., \& Karcher, M. J. (2016). Correctional counselor burnout: Examining burnout rates using the Counselor Burnout Inventory. Journal of Offender Rehabilitation, 55(3), 195-212. 
Carson, E. A. (2018). Prisoners in 2016. Washington DC: U.S. Department of Justice, Office of Justice Programs, Bureau of Justice Statistics.

Chapman, J. B. (1972). Workload regulation: The case for purposive action. Probation Journal, 18(1), 8-11.

Cooper, H. (2010). Research synthesis and meta-analysis: A step-by-step approach (4 ${ }^{\text {th }}$ ed.). Thousand Oaks, CA: Sage.

Council of State Governments Justice Center. (2018a). Iowa's statewide recidivism reduction strategy: Highlights and progress. New York, NY.

Council of State Governments Justice Center. (2018b). Strengthening correctional culture: Eight ways corrections leaders can support their staff to reduce recidivism. New York, NY.

Council of State Governments Justice Center. (2018c). Second Chance Act spotlight: Grant awards help Iowa corrections officers focus efforts to improve reentry outcomes. New York, NY.

Coyle, A., Fair, H., Jacobson, J., \& Walmsley, R. (2016). Imprisonment worldwide: The current situation and an alternative future. Chicago, IL: Policy Press.

Cuddeback, G. S., Gayman, M., \& Bradley-Engen, M. (2011). North Carolina probation/parole caseload standards and practices. Raleigh, NC: North Carolina Department of Corrections.

Davidson, C. (2012). 2012 Iowa Board of Parole risk assessment validation. Des Moines, IA: Iowa Department of Human Rights, Division of Criminal and Juvenile Justice Planning, Statistical Analysis Center. 
DeMichele, M. T. (2008). Probation and parole's growing caseloads and workload allocation: Strategies for managerial decision making. Lexington, KY: Council of State Governments, American Probation and Parole Association.

DeMichele, M. T., \& Payne, B. K. (2007). Probation and parole officers speak out: Caseload and workload allocation. Federal Probation, 71(3), 30-35.

DeMichele, M. T., \& Payne, B. K. (2012). Measuring community correstions' officials perceptions of goals, strategies, and workload from a systems perspective: Differences between directors and nondirectors. The Prison Journal, 92(3), 388-410.

DeMichele, M. T., \& Payne, B. K. (2018). Taking officer time seriously: A study of the daily activities of probation officers. Probation Journal, 65(1), 39-60.

DeMichele, M. T., Payne, B. K., \& Matz, A. K. (2011). Community supervision workload considerations for public safety. Lexington, KY: Council of State Governments, American Probation and Parole Association.

Dowden, C., \& Andrews, D. A. (2004). The importance of staff practice in delivering effective correctional treatment: A meta-analytic review of core correctional practices. International Journal of Offender Therapy and Comparative Criminology, 48(2), 203214.

Edwards, A., Hughes, G., \& Lord, N. (2013). Urban security in Europe: Translating a concept in public criminology. European Journal of Criminology, 10(3), 260-283.

Fahoome, G. F. (2002). Twenty nonparametric statistics and their large sample approximations. Journal of Modern Applied Statistical Methods, 1(2), 248-268. 
Fletcher, A. J., \& Marchildon, G. P. (2014). Using the Delphi method for qualitative, participatory action research in health leadership. International Journal of Qualitative Methods, 13(1), 1-18.

Frankfort-Nachmias, C., \& Leon-Guerrero, A. (2011). Social statistics for a diverse society (6 ${ }^{\text {th }}$ ed.). Thousand Oaks, CA: Sage.

Gavrielides, T. (2008). Restorative justice--the perplexing concept: Conceptual fault-lines and power battles within the restorative justice movement. Criminology \& Criminal Justice, $8(2), 165-183$.

Gill, F. E. (2003). Moral benefit of Punishment: Self-determination as a goal of correctional counseling. Lanham, MD: Lexington Books.

Green, R. A. (2014). The Delphi technique in educational research. Sage Open, 4(2), 1-8.

Greenwood, P. (2014). Evidence-based practice in juvenile justice: Progress, challenges, and opportunities. New York, NY: Springer.

Griesse, N. (2008). 2007 workload study. Sioux Falls, SD: State of South Dakota, Board of Pardons and Paroles.

Haas, S. M., \& Spence, D. H. (2016). Use of core correctional practice and inmate preparedness for release. International Journal of Offender Therapy and Comparative Criminology.

Hanser, R. D., \& Mire, S. M. (2011). Correctional counseling. Upper Saddle River, NJ: Pearson Education.

Hardyman, P. L. (1999). Redefining community supervision strategies for Montana Bureau of Probation and Parole. Washington, DC: U.S. Department of Justice, National Institute of Corrections. 
Hardyman, P. L. (2001). Computation of the workload formula for the Montana Bureau of Probation and Parole: Revised. Washington, DC: U.S. Department of Justice, National Institute of Corrections.

Iowa Department of Corrections. (2016). Prison Recidivism FY2016: Research in brief.

Kelley, T. M. (2008). Principle-based correctional counseling: Teaching health versus treating illness. Applied Psychology in Criminal Justice, 4(2), 182-205.

Kennedy, D. B. (1984). Clinical sociology and correctional counseling. Crime \& Delinquency, 30(2), 269-293.

Kleiman, M., Lee, C. G., \& Ostrom, B. J. (2013). Workload assessment: A data-driven management tool for the judicial branch. In The Book of the States (pp. 243-247). Lexington, KY: Council of State Governments.

Kratcoski, P. C. (2004). Correctional counseling and treatment (5th ed.). Long Grove, IL: Waveland Press.

Lee, L. M. (2017). The impact of prison programming on recidivism. Corrections: Policy, Practice and Research.

Lehman, W. E., Greener, J. M., Rowan-Szal, G. A., \& Flynn, P. M. (2012). Organizational readiness for change in correctional and community substance abuse programs. Journal of Offender Rehabilitation, 51(1/2), 96-114.

Matz, A. K., Conley, T. B., \& Johanneson, N. (2018). What do supervision officers do? Adult probation/parole officer workloads in a rural Western state. Journal of Crime and Justice, 41(3), 294-309.

Miles, A. P. (1969). Time studies in probation and parole. Crime \& Delinquency, 15(2), 259-266.

Orme, J. (1988). Can workloads be measured? Probation Journal, 35(2), 57-59. 
Payne, B. K., \& DeMichele, M. T. (2011). Probation philosophies and workload considerations. American Journal of Criminal Justice, 36(1), 29-43.

Ringgenberg, J. (2017). Iowa Department of Corrections FY2017 annual report. Des Moines, IA: Iowa Department of Corrections.

Salkind, N. J. (2011). Statistics for people who (think they) hate statistics. Thousand Oaks, CA: Sage.

Schrink, J. (1997). Understanding the correctional counselor. In P. Van Voorhis, M. Braswell, \& D. Lester, Correctional counseling and rehabilitation (3rd ed., pp. 41-60). Cincinnati, $\mathrm{OH}$ : Anderson Publishing.

Schrink, J., \& Hamm, M. S. (1989). Misconceptions concerning correctional counseling. Journal of Offender Counseling, Services \& Rehabilitation, 14(1), 133-147.

Sterling Associates. (2002). Washington State Department of Corrections: Community Corrections: Workload study final report.

Sun, K. (2008). Correctional counseling: A cognitive growth perspective. Boston, MA: Jones and Bartlett.

Sundt, J. L., Dammer, H. R., \& Cullen, F. T. (2002). The role of the prison chaplain in rehabilitation. Journal of Offender Rehabilitation, 35(3/4), 59-87.

Tallarico, S., Douglas, J., \& Fogg, V. (2010). North Dakota juvenile court officer weighted workload assessment study. Denver, CO: National Center for State Courts, Court Services Division.

Tallarico, S., Douglas, J., Friess, E., \& Hall, D. J. (2009). Colorado judicial branch probation officer updated workload values study. Denver, CO: National Center for State Courts, Court Services Division. 
Tallarico, S., Douglas, J., Kinney, E., \& Murphy, M. (2007). South Dakota unified judicial system court services officers weighted workload assessment study. Denver, CO: National Center for State Courts, Court Services Division.

Tallarico, S., Douglas, J., Tomlinson, K., \& Hall, D. (2010). Alabama juvenile probation officer weighted workload assessment study. Denver, CO: National Center for State Courts, Court Services Division.

Twigg, D., \& Duffield, C. (2008). A review of workload measures: A context for a new staffing methodology in Western Australia. International Journal of Nursing Studies, 46(1), 132140.

Van Voorhis, P., \& Salisbury, E. J. (2014). Correctional counseling and rehabilitation (8th ed.). Anderson Publishing.

Van Wormer, K. (1999). The strengths perspective: A paradigm for correctional counseling. Federal Probation, 63(1), 51-58.

Wagner, D., \& Connell, S. (2004). North Dakota Department of Corrections and Rehabilitation Field Services Division: Probation and parole workload study. Madison, WI: National Council on Crime and Delinquency.

Walmsley, R. (2018). World prison population list (12th ed.). Birkbeck, University of London, Institute for Criminal Policy Research.

Washington Department of Corrections. (2005). Community corrections workload study final report. Olympia, WA: Author. 
Adam K. Matz, PhD, is an Assistant Professor in the Department of Criminal Justice at the University of North Dakota. He previously worked in research positions with the American Probation and Parole Association and the Kentucky Court of Justice.

Nathan C. Lowe, PhD, is the Program Director of Grants and Research with the American Probation and Parole Association. He is involved in various grant-funded projects concerning the provision of training, technical assistance, and research/evaluation. 
Table 1

Correctional Counselor and Inmate Demographical Information

\begin{tabular}{|c|c|c|c|c|}
\hline \multirow[b]{2}{*}{ Variable } & \multicolumn{2}{|c|}{ Counselors $(N=117)$} & \multicolumn{2}{|c|}{ Inmates $(N=4,844)$} \\
\hline & $n$ & $\%$ & $n$ & $\%$ \\
\hline \multicolumn{5}{|l|}{ Facility } \\
\hline Anamosa State Penitentiary (ASP) & 10 & 8.5 & 375 & 7.7 \\
\hline Luster Heights (LH) & 1 & 0.9 & 25 & 0.5 \\
\hline Clarinda Correctional Facility (CCF) & 9 & 7.7 & 314 & 6.5 \\
\hline Fort Dodge Correctional Facility (FDCF) & 14 & 12.0 & 698 & 14.4 \\
\hline Iowa Correctional Institution for Women (ICIW) & 10 & 8.5 & 262 & 5.4 \\
\hline Minimum Live-Out (MLO) & 2 & 1.7 & 88 & 1.8 \\
\hline Iowa Medical \& Classification Center (IMCC) & 14 & 12.0 & 874 & 18.0 \\
\hline Iowa State Penitentiary (ISP) & 10 & 8.5 & 215 & 4.4 \\
\hline John Bennett Correctional Center (JBCC) & 1 & 0.9 & 108 & 2.2 \\
\hline Mount Pleasant Correctional Facility (MPCF) & 12 & 10.3 & 538 & 11.1 \\
\hline Newton Correctional Facility (NCF) & 15 & 12.8 & 707 & 14.6 \\
\hline Correctional Release Center (CRC) & 4 & 3.4 & 169 & 3.5 \\
\hline North Central Correctional Facility (NCCF) & 6 & 5.1 & 278 & 5.7 \\
\hline Other & 0 & 0.0 & 151 & 3.1 \\
\hline Missing & 9 & 7.7 & 42 & 0.9 \\
\hline \multicolumn{5}{|l|}{ Sex } \\
\hline Female & 53 & 45.3 & 363 & 7.5 \\
\hline Male & 64 & 54.7 & 4,481 & 92.5 \\
\hline \multicolumn{5}{|l|}{ Race } \\
\hline American Indian and Alaskan Native & 1 & 0.9 & 74 & 1.5 \\
\hline Asian or Pacific Islander & 0 & 0.0 & 40 & 0.8 \\
\hline Black or African American & 7 & 6.0 & 1,237 & 25.5 \\
\hline White/Caucasian & 89 & 76.1 & 3,492 & 72.1 \\
\hline Other & 6 & 5.1 & 0 & 0.0 \\
\hline Missing & 14 & 12.0 & 1 & 0.0 \\
\hline \multicolumn{5}{|l|}{ Hispanic/Latino } \\
\hline Yes & 3 & 2.6 & 291 & 6.0 \\
\hline No & 114 & 97.4 & 4,546 & 93.8 \\
\hline Age $(n=106)$ & $M=47.6$ & $S D=9.6$ & & \\
\hline Years in Current Position $(n=106)$ & $M=11.3$ & $S D=8.4$ & & \\
\hline Years at Department of Corrections $(n=108)$ & $M=15.3$ & $S D=9.3$ & & \\
\hline
\end{tabular}

Note. In relation to facility “other” includes inmates housed at the ANCHOR Residential Center $(n=2)$, Burlington Residential Facility $(n=1)$, Counsil Bluff's Residential Facility $(n=1)$, Forensic Psychiatric Hospital $(n=14)$, Des Moines Women’s Residential Correctional Center $(n=$ 1), Larry A. Nelson Residential Center $(n=1)$, and the Lodge $(n=132)$. 
Table 2

Frequency and Time (in minutes) of Activities

\begin{tabular}{|c|c|c|c|c|c|c|c|c|}
\hline Activity & $n$ & $\%$ & Max. & $M$ & $S D$ & $\Sigma$ & $\%$ & $\begin{array}{c}\text { Inadequate } \\
\text { Time (\%) }\end{array}$ \\
\hline \multicolumn{9}{|l|}{ Inmate-Focused Activities } \\
\hline Inmate Requests & 4,971 & 15.9 & 380 & 17.0 & 20.9 & 84,525 & 8.9 & 35.6 \\
\hline Inmate Work & 2,920 & 9.3 & 390 & 20.3 & 26.8 & 59,150 & 6.2 & 26.8 \\
\hline Classification & 2,555 & 8.1 & 480 & 30.5 & 39.4 & 77,995 & 8.2 & 29.1 \\
\hline Assessments & 2,213 & 7.1 & 420 & 25.7 & 32.3 & 56,908 & 6.0 & 49.8 \\
\hline Release Planning & 2,127 & 6.8 & 400 & 19.4 & 21.4 & 41,244 & 4.3 & 27.1 \\
\hline Treatment Group Work & 1,574 & 5.0 & 450 & 66.0 & 58.8 & 103,838 & 10.9 & 29.1 \\
\hline Reception Work & 1,274 & 4.1 & 270 & 33.8 & 35.7 & 43,060 & 4.5 & 46.2 \\
\hline ICON Entries & 1,159 & 3.7 & 360 & 20.4 & 26.7 & 23,664 & 2.5 & 32.8 \\
\hline Institution Case Plan & 856 & 2.7 & 265 & 26.9 & 21.2 & 22,991 & 2.4 & 27.8 \\
\hline Security Checks & 573 & 1.8 & 150 & 27.8 & 21.4 & 15,924 & 1.7 & 28.3 \\
\hline Inmate Checks & 488 & 1.6 & 145 & 19.0 & 18.1 & 9,274 & 1.0 & 45.3 \\
\hline Special Lists & 287 & 0.9 & 210 & 22.6 & 26.1 & 6,472 & 0.7 & 36.2 \\
\hline Sex Offender & 161 & 0.5 & 360 & 20.8 & 32.5 & 3,341 & 0.4 & 19.9 \\
\hline Keep Separates & 63 & 0.2 & 60 & 14.6 & 11.8 & 922 & 0.1 & 38.1 \\
\hline \multicolumn{9}{|l|}{ Other Occupational Activities } \\
\hline Administrative Work & 4,596 & 14.7 & 720 & 24.0 & 37.1 & 110,474 & 11.6 & 35.7 \\
\hline Coverage Work & 980 & 3.1 & 480 & 25.4 & 35.8 & 24,860 & 2.6 & 19.8 \\
\hline Professional Development & 849 & 2.7 & 690 & 122.1 & 164.4 & 103,673 & 10.9 & 27.7 \\
\hline Program Sponsor & 235 & 0.7 & 510 & 38.7 & 57.4 & 9,101 & 1.0 & 32.8 \\
\hline Quality Assurance & 134 & 0.4 & 200 & 51.7 & 43.1 & 6,913 & 0.7 & 37.3 \\
\hline Court Reporting & 63 & 0.2 & 90 & 23.7 & 19.8 & 1,490 & 0.2 & 28.6 \\
\hline Other & 519 & 1.7 & 540 & 26.5 & 49.0 & 13,769 & 1.4 & 36.0 \\
\hline \multicolumn{9}{|l|}{ Non-Occupational Activities } \\
\hline Time Study Documentation & 2,117 & 6.8 & 120 & 19.8 & 16.2 & 41,859 & 4.4 & 34.6 \\
\hline Staff Leave & 638 & 2.0 & 600 & 138.4 & 161.3 & 88,291 & 9.3 & 38.4 \\
\hline
\end{tabular}


Table 3

Characteristics of Activity Contact

\begin{tabular}{|c|c|c|c|c|c|c|c|}
\hline Activity Characteristic & $n$ & $\%$ & Max. & $M$ & $S D$ & $\Sigma$ & $\%$ \\
\hline \multicolumn{8}{|l|}{ Primary person involved } \\
\hline Inmates (i.e., individually) & 11,963 & 38.2 & 450 & 18.2 & 20.9 & 217,389 & 22.9 \\
\hline Staff (e.g., correctional officers) & 2,512 & 8.0 & 570 & 34.9 & 74.2 & 87,611 & 9.2 \\
\hline Group (i.e., multiple offenders) & 1,531 & 4.9 & 480 & 59.8 & 58.8 & 91,545 & 9.6 \\
\hline Treatment Providers & 472 & 1.5 & 450 & 46.2 & 55.7 & 21,783 & 2.3 \\
\hline Inmates’ Family & 383 & 1.2 & 320 & 14.8 & 23.2 & 5,679 & 0.6 \\
\hline Supervisors & 310 & 1.0 & 210 & 20.2 & 23.8 & 6,271 & 0.7 \\
\hline Administrative Staff & 218 & 0.7 & 180 & 27.2 & 25.7 & 5,927 & 0.6 \\
\hline Board of Parole & 78 & 0.2 & 240 & 30.0 & 38.4 & 2,335 & 0.2 \\
\hline Attorneys & 75 & 0.2 & 107 & 10.3 & 14.1 & 771 & 0.1 \\
\hline Public & 53 & 0.2 & 180 & 28.1 & 39.2 & 1,489 & 0.2 \\
\hline Law Enforcement & 16 & 0.1 & 45 & 11.3 & 11.7 & 181 & 0.0 \\
\hline Victims/Victims’ Families & 10 & 0.0 & 75 & 20.4 & 21.3 & 204 & 0.0 \\
\hline Court (e.g., judge) & 9 & 0.0 & 25 & 11.1 & 7.0 & 100 & 0.0 \\
\hline Multiple Individual Types & 2,966 & 9.5 & 720 & 38.5 & 59.0 & 114,200 & 12.0 \\
\hline Other (e.g., medical personnel) & 1,309 & 4.2 & 720 & 48.1 & 78.2 & 62,963 & 6.6 \\
\hline Not Applicable (i.e., solitary) & 9,447 & 30.1 & 600 & 35.1 & 65.3 & 331,290 & 34.9 \\
\hline \multicolumn{8}{|l|}{ Method of contact } \\
\hline In Person (i.e., face-to-face) & 11,999 & 38.3 & 720 & 31.4 & 48.4 & 376,172 & 39.6 \\
\hline Computer (e.g., virtual meetings) & 10,930 & 34.9 & 480 & 28.0 & 41.6 & 306,008 & 32.2 \\
\hline Electronic Mail (e.g., email, kiosk) & 3,257 & 10.4 & 330 & 15.6 & 17.2 & 50,705 & 5.3 \\
\hline Office Phone (e.g., checking voicemail) & 1,762 & 5.6 & 200 & 13.6 & 15.6 & 23,990 & 2.5 \\
\hline Mail & 162 & 0.5 & 75 & 17.1 & 13.6 & 2,767 & 0.3 \\
\hline Not Applicable (i.e., solitary) & 3,242 & 10.3 & 720 & 58.6 & 106.8 & 190,096 & 20.0 \\
\hline
\end{tabular}

Note. $N=31,352$. 